\title{
GENRE SPECIFIC OF J. GENET'S NOVELS
}

\section{Semenets O. S.}

\section{INTRODUCTION}

French fiction is an inexhaustible practical basis for history and theory researchers of the autobiographical genre. Autobiography becomes logical and natural basis for creativity, and its elements enrich and transform various literary genres. In the twentieth century, the genre of autobiography was increasingly drawn to artistic autobiography and autopsychologism. Thus, the representatives of this transformed genre are R. Bart, K. Moriak, who joined the writing of autobiographical prose only in 1974, the late works of M. Leri, N. Sarrot, J-P. Sartre, J. Genet, and others. An important function is given to the fictitious possibilities of autobiography as a means of self-discovery.

J. Genet's novels do not fit within the narrow bounds of "classic" autobiography as "biography", but are characterized by the category of "autobiography" (the author himself emphasized it in non-textual reality repeatedly) as a principle of correlation between artistic and extra-ordinary reality, which consists in the transformation of autobiographical vital material. The genre of prose works by J. Genet is defined as a "novel", which, in turn, "sanctions fiction and postulates the nonidentity of life and text reality". Such a cognitive game with narrator identity throughout the work keeps the reader in suspense. From the beginning of the reading he expects the sincerity of the author and forgives him the unconscious autofiction, the memory failure, as the author constantly reproaches himself for them. However, when the author deliberately confuses the reader in the metatextual discourse, questioning the referentiality of the facts he has just assured, the latter finally loses his sense of reality.

Emphasizing the cognitive importance of the fictitious for himself, J. Genet also performs a communicative act with an implicit or explicit reader, based on his declared sincerity. Forms of expression of sincerity in a story for a writer are confession in homosexuality and a desire for transvestism, recognition of his worthlessness and insecurity. In addition, stylistic and linguistic "markers" of the autobiographical genre widely used by Jean Genet as a means of influencing the reader to ultimately confuse the reader. 


\section{Autofiction as a defining feature of $J$. Genet s prose}

The general principle that has allowed researchers to combine novels into one genre system is, at first glance, a sufficiently transparent "autobiographical agreement” (a concept introduced by Ph. Lejeune ${ }^{1}$ ). Sometimes a treaty "concluded" by Jean Genet with readers, recorded in the title of the work ("The Thief's Journal"), in other cases in the preamble ("Our Lady of the Flowers", "Funeral Rites") or in the explanatory notes and comments ("Querelle of Brest", "Miracle of the Rose"). The so-called "autobiographical intention" is also confirmed in many articles and notes, in interviews that the writer willingly gave, emphasizing the autobiographical nature of his works. For example, every book by J. Genet is written with a certain intention, which is already known to the reader from the first pages ("S'il est vrai qu'il a pour but avoué de dire la gloire de Jean D., il a peut-être des buts seconds plus imprévisibles. <...>. Il est troublant qu'un thème macabre m'ait été offert il y a longtemps, afin que je le traite aujourd'hui et l'incorpore malgré moi à un texte chargé de décomposer le rayon lumineux, fait surtout d'amour et de douleur, que projette mon coeur désolé", or "J'eusse désiré dans ce livre faire une apologie aussi du vol. J'aimerais que mes petits compagnons aient été d'élégants voleurs, vifs comme le Mercure”3.

At the same time J. Genet emphasizes the fictional nature of his works in numerous speeches and comments. In addition, the author positions the works as "novels", despite their overt autobiography. He violates the conditions of the fundamental autobiography its "autobiographical agreement" and at the same time he does not adhere to the "novel agreement" (the guidance on the exclusively fictional nature of the work). There is a process that, will be called an "autofiction agreement" almost forty years after J. Genet`s novels were written, (by T. Laurent). To make such a decision, the author confesses that, he did not want or could not be completely frank, telling about his life, so he turned to the fable ${ }^{4}$.

J. Genet abuses the fictional features of the autobiographical genre, but gives a leading role to fiction in his novels as an embodiment of his dreams and fantasies. It is fiction (the proportion of fiction is significantly increases from "Miracle of the Rose" to "Querelle of Brest"), which is inextricably associated with the depicted reality, allows us to get an idea

\footnotetext{
${ }^{1}$ Lejeune P. Le pacte autobiographique. / P. Lejeune. Paris: Ed. du Seuil, 1975. 330 p.

${ }^{2}$ Genet J. Pompes Funèbres / Jean Genet. Paris, Gallimard, 1953. P. 9.

${ }^{3}$ Genet J. Miracle de la rose // Oeuvres completes de Jean Genet / Jean Genet. II. Paris, Gallimard, 1952. P. 227.

${ }^{4}$ Laurent Th. L'oeuvre de Patrick Modiano : une autofiction / Th. Laurent. Lyon: Presses universitaires de Lyon, 1997. P. 20-21.
} 
of the writer's inner world, to make his psychological portrait. This allows us to assert that J. Genet's prose is more autopsychobiographical (according to L. Ginzburg ${ }^{5}$ ) than autobiographical. The leading role in it is the depiction of the individual inner world formation, not the formation of the lyrical hero as a man of history.

Due to the appearing definition of the contemporary autobiography genre as autofiction, a new point of view on the genre identification by Jean Genet`s novels has appeared. In S. Dubrovsky`s opinion among autofictional works "Nadja" by A. Breton, "La naissance du jour" by S. G. Colette, German trilogy "D’un château l'autre”, "Nord”, "Rigodon” by L.F. Celine he also called the "Journal du voleur" by J. Genet. Other researchers began to follow him (F. Gasparini, V. Colonna, J. Lecarme) and study the novels of J. Genet "The Thief"s Journal", "Miracle of the Rose", "Our Lady of the Flowers" as the examples of autofiction.

According to S. Dubrovsky" "autofiction" as a literary genre is defined by the following characteristics:

1) onomastic identity of the author and narrator;

2) subtitled "novel";

3) the primacy of the narrative;

4) study of the original form;

5) the manner of the letter, which seeks to "la verbalisation immédiate" (“instant verbalization");

6) reconfiguration of linear time (through selection, intensification, stratification, fragmentation, confusion, etc.);

7) extensive use of the present in the narrative;

8) an obligation to describe only true facts and events;

9) the unconscious pursuit of "se révéler dans sa vérité" ("Find yourself in your truth”);

$10)$ the strategy of alienation of the reader.

However, none of the works classified by S. Dubrovsky as autofiction contained all ten features. As for the J. Genet`s novel, "The Thief's Journal"7, it lacks the fifth, eighth and tenth signs. According to other researchers of autofiction (J. Lecarme ${ }^{8}$, F. Gasparini ${ }^{9}$,

\footnotetext{
${ }^{5}$ Гинзбург Л. Я. О психологической прозе / Гинзбург Лидия Яковлевна. Л. : Художественная литература, ЛО, 1977. 443 с. - Библиогр. в подстроч. примеч.

6 Doubrovsky S. Autobiographie / Vérité / Psychanalyse / S. Doubrovsky // Autobiographiques : de Corneille à Sartre. - Paris : PUF, coll. "Perspectives critique”, 1988. - P. 61-79.

${ }^{7}$ Genet J. Journal du Voleur / Jean Genet. Paris, Gallimard, 1949. 320 p.

${ }^{8}$ Lecarme J. Autofiction : un mauvais genre / J. Lecarme // Autofictions et Cie. Actes du colloque des 20 et 21 novembre 1992 / [dir. S. Doubrovsky, P. Lejeune, J. Lecarm]. revue PITM. n 6. Paris. 1993. P. $227-249$.

${ }^{9}$ Gasparini Ph. Est-il je? Roman autobiographique et autofiction / Ph. Gasparini. Paris: Editions du Seuil, Coll. Poétique. 2004. 393 p.; Gasparini Ph. Une aventure du langage / Ph. Gasparini. Paris: Le Seuil, 2008. 339 p.
} 
F. Vilen ${ }^{10}$ ), who used S. Dubrovsky`s definition in their explorations, the compliance with the most characteristics serves to position the work as autofiction.

J. Lecarme insisted on only two first signs: the label "novel" and the onomastic identity of the author-narrator-hero. However, F. Gasparini ${ }^{11}$, polemicizing with J. Lecarme, noted that the subtitle "novel" could be given by publisher, or the author himself tried to provide a space of his own texts in the fiction. As for J. Genet's prose, the subtitle "novel" appears in all five novels under study. However, the author in the text refers only to the work "Querelle of Brest": "Si l'on s'étonne (nous disons s'étonner plutôt que s'émouvoir ou s'indigner afin de mieux montrer que ce roman veut être démonstratif) <... ${ }^{\prime 12}$. All other prose works he calls either simply "book” or “drama”, “poem”, "legend”, “fairy tale”, “song of love". In addition, the style of J. Genet is so poetic that most foreign and domestic researchers do tend to believe that the writer wrote a kind of "poetry in prose".

By the degree of awareness of J. Genet`s novel fictionalization, unlike the unconscious (forced) autofiction, it is voluntarily fictionalized (sometimes it casts doubt on the real facts, sometimes deforms them in favor of its own ethical-aesthetic concept, sometimes tries to convince the true to believe ). This illustrates the opinion of $\mathrm{M}$. Darrieussecq ${ }^{13}$, supported by J. Jeanette, V. Colonna and F. Gasparini, about the hybridity of the autofiction genre.

The text "The Thief's Journal" as a practice of creating the author's personality is not a reflection of the vertical becoming of his personality, but it's a reflection of horizontal direct emotional state, when the writer has finally determined his social position of the marginal and the outcast, finding refuge in the world of illusions. The form of an arbitrary diary is used rather to encourage the reader, since the interest in the literature of memoirs; the inner world of the writer is also a defining feature of the literary process of the twentieth century.

In establishing the autobiographical nature of V. Colonna`s fictional works, following his teacher J. Genet, appeals to non-textual realities and suggests paying attention to their titles in handwritten versions and first

\footnotetext{
${ }^{10}$ Vilain P. L' autofiction en théorie / P. Vilain // Genèse et autofiction / [dir. J.-L. Jeannelle et C. Viollet]. Louvain-la-Neuve: Bruylant-Academia, 2007. Pp. 70-75.

11 Gasparini Ph. Est-il je? Roman autobiographique et autofiction / Ph. Gasparini. Paris: Editions du Seuil, Coll. Poétique. 2004. 393 p.

${ }^{12}$ Genet J. Querelle de Brest / Jean Genet. Paris, Gallimard, 1953. P. 218.

${ }^{13}$ Darrieussecq M. L'autofiction, un genre pas sérieux / M. Darrieussecq // Poétique. № 107. septembre 1996. P. 369-380.
} 
editions, if the work's title does not reflect the author's autobiographical intent (as in the case of “The Thief's Journal” and “Querelle of Brest”).

Having been imprisoned in 1942 for the theft of the books by M. Proust and P. Verlaine, J. Genet begins to write the first prose work "Our Lady of the Flowers", which in the first version was entitled "Prison of Fran, 1942" (Prison de Fresnes, 1942). The writer continued to work on the novel after his release, working as a book salesman at a secondhand book store on embankment of the river Seine, but in April of that year he was arrested again for the appropriation of books. Again, after being jailed for theft in 1943, in the prison of Santa, the writer began to work on the second novel, "Miracle of the Rose", which was originally called "Sante. Turelle Prison, 1943” (La Santé. Prison de Tourelles 1943).

With regard to the onomastic identity of the author and the heronarrator, this criterion is also questioned in the studies of foreign literary critics. F. Gasparini, and after him, V. Colonna, believes that the identity of the author-narrator-hero cannot interfere with the factualisation of facts, and the uniqueness of the names, in turn, will not significantly affect the positioning of the work as autobiographical, since it is autobiographical and partial coincidence the author and the narrator will be provided with extra and intertextual links. S. Dubrovsky has already called such autofiction as "quasi-autofiction", and P. Wilen has called it "autofiction anominale" ("non-nominal autofiction”).

With regard to the novels of J. Genet, in "Our Lady of Flowers", "Funeral Rites", "The Thief`s Journal" there is a combination of "nominal" and "non-nominal" autofiction in autofictional narrative. In the first novel, the autopsychobiographical line is interspersed with the Divine's fictional story, which is the author's autoplotalisation. The story of his stay in Fresno is not accompanied by really confirmed facts (name identity), but it looks like the first awkward but successful attempt at self-reflection. According to D. Stakhov, it is "a polylogue with itself, where all the heroes of the novel are welcome" ${ }^{\text {" }}$. The narrator seems to be writing a diary in prison. But this diary is devoid of events. We learn about the life of the narrator only fragmentarily and thanks to the heroes of his dreams, the actions of which cause the author to plunge into the memories. They are fictitious and collective images of those criminals who have met or written about the writer, but are endowed with features inherent in him, each of them in some sense is J. Genet himself. The writer creates new personalities, wearing masks of certain fictional characters, trying to find

\footnotetext{
${ }^{14}$ Стахов Д. Святой? Комедиант? Мученик? / Д. Стахов // Новый мир. М., 1995. № 2. С. $236-239$.
} 
himself real. The protagonist of the novel Lou Kulafroix, a partial prototype of the image of which was the writer himself, had a past, a childhood, and a mother. Divine's world (that was his second name) was not limited to the environment of criminals and pervert, but had another, normal dimension. In the text, we find: "Et refaire à ma guise, et pour l'enchantement de ma cellule (<..>), l'histoire de Divine que je connus si peu, l'histoire de Notre-Dame-des-Fleurs, et n'en doutez pas, ma propre histoire”"15, or “<...> Mignon m'eût déchargé jusqu'au coeur. Entrant en moi jusqu'à n'y plus laisser de place pour moi-même <...>”16.

Most of the characters (not the main ones) of his works have Jean name, only surnames and nicknames are different. In almost every hero, J. Genet is guessed, he seems to invent himself new and new personalities, predicts himself in different situations, which is already autofictional in the broad sense of the term (according to V. Colonna), when inventing himself has an autobiographical intention to be realized in unrealized situations. Experiencing the fate of your characters, a writer in his works can become one who never dares to be in real life ("C'est un autre Jean, ici, qui me raconte son histoire. Je ne suis plus seul, mais de ce fait je suis plus seul que jamais. Je veux dire que la solitude de la prison me donnait cette liberté d'être avec les cent Jean Genet entrevus au vol chez cent passant, car je suis bien pareil à Mignon <..>"17). Y. Pokalchuk called "Our Lady of the Flowers" "a remembrance of what was not, and a dream of what cannot be" ${ }^{\text {"18 }}$.

After numerous discussions that have arisen about the new genre formation and its inaccuracy / identity with the autobiographical novel, since 1984 one of the main features of this genre has been formulated: autofiction began to be characterized as "ethics based on systematic doubt"19. F. Gasparini, summarizing the research on the subject, noted that "self-critical methodological discourse becomes thus a characteristic sign of a new genre" 20 .

He, summing up the results of his intelligence and research of his colleagues, found among others the following explicit operators of the genre complication:

- documentary historical evidence;

\footnotetext{
${ }^{15}$ Genet J. Notre-Dame des Fleurs / Jean Genet. - Lyon: Barbezat-L'Arbalète, 1948. - P. 17.

16 Ibid. P. 22.

${ }^{17}$ Ibid. P. 305.

${ }^{18}$ Покальчук Ю. Дзеркальні лабіринти «святого» Жене / Ю. Покальчук // Покоївки : [П'єса] / Жан Жене ; [пер. із фр. та післямова Ю. Покальчука]. Львів: Кальварія, 2002. С. 97.

${ }^{19}$ Gasparini Ph. Une aventure du langage / Ph. Gasparini. Paris: Le Seuil, 2008. P. 31.

${ }^{20}$ Ibid. P. 211.
} 
- literary intertextuality;

- self-citation;

- mirroring;

- methodological discourse.

The literary intertextuality of autobiographical discourse, which points to its relation to other discourses, refers to certain historical and cultural facts. According to N. Nikolina, "foreign texts contribute to the creation of both an image of the era, which serves as the subject of memories, and the image of the narrator" ${ }^{21}$. J. Genet's novels are full of various intertextual elements. This is an:

- ancient mythology (for example "Sans bouger un muscle, mais se bandant, elle lutta en elle comme le Laocoon saisit le monstre et le tordit" ${ }^{22}$,

- Scripture, French folklore "Bien avant que d'entrer dans les Equipages de la Flotte, Querelle avait entendu la chanson intitulée "l'Etoile d'Amour":

"Tous les marins ont une étoile

Qui les protège dans les cieux.

Quand à leurs yeux rien ne la voile

Le malheur ne peut rien contre eux" ${ }^{23}$ ),

- literary works “<..> les marlous portaient rose et chapeau, à qui Villon disait:

Beaux enfants, vous perdez la plus

Belle rose de vos chapeaux..." 24 ),

- documents (mainly newspaper titles and excerpts of articles about murderers, details from their criminal cases: " "Pendant les deux années qu'il passa au corps de la Marine, sa nature insoumise, dépravée, lui valut soixante-seize punitions. Il tatouait les novices, volait ses camarades, et se livrait sur les animaux à des actes étranges". (Relationdu procès de Louis Ménesclou âgé de 20 ans. Exécuté le 7 septembre 1880)"”25),

- texts created by Jean Genet (a constant reminiscence of his earlier works).

All of these elements destroy the closed world of the individual text and complicate the structure of the narrative. The use of intertext requires

${ }^{21}$ Николина Н. А. Поэтика русской автобиографической прозы : Учебное пособие для студентов, аспирантов, преподавателей-филологов : / Николина Наталья Анатольевна. М. : Флинта; Наука, 2002. C. 353.

${ }^{22}$ Genet J. Notre-Dame des Fleurs / Jean Genet. Lyon: Barbezat-L'Arbalète, 1948. P. 125.

${ }^{23}$ Genet J. Querelle de Brest / Jean Genet. Paris, Gallimard, 1953. P. 206.

${ }^{24}$ Genet J. Miracle de la rose // Oeuvres completes de Jean Genet / Jean Genet. II. Paris, Gallimard, 1952. P. 177.

${ }^{25}$ Genet J. Querelle de Brest / Jean Genet. Paris, Gallimard, 1953. P. 8. 
the activity of the reader and reduces the gap between the addressee of the work and its author by outlining common knowledge.

In a detailed study of J. Genet's novel, his tendency to use as intertextual sources of mythological and biblical images undergoing reinterpretation and transformation is. Appeals to them bring personal situations of the past represented to certain archetypes. First, this tendency is a sign of the autobiographical genre of the twentieth century, which appeals "to the inner expanses of human consciousness" 26 , in which, along with the increase in subjectivity, the degree of generalization increases. In addition to the source of imagery, mythological principles are also universal schemes that appeal to the subconscious of the reader. Secondly, J. Genet's attempt to create his own "Christian inherently",27 system of world perception that could not but be based on an interpretation of world religion. The tendency to use mythological images as artistic metaphors amplified the effect of the text, fulfilling the ornamental function, the function of analogy and the figurative characteristics of the individual realities described. Thus, in describing the fight between two brothers, Querelle and Roger, the narrator states: " $\mathrm{La}$ rue devenait un passage de la Bible où deux frères dirigés par deux doigts d'un seul Dieu s'insultent et se tuent pour deux raisons qui n'en sont qu'une"28.

Since the use of various intertextual elements that generalize and typify the depicted is a means of indirect or direct characterization of the narrator himself, it can be assumed that in this way J. Genet tried to get rid of the widespread belief that he is illiterate man who did not even finish high school.

Self-quoting, constant references to previous texts, discussion in the numerous indentations of the basic tenets of one's own theatrical concept of "theater in the cemetery" are, at the formal level, a manifestation of intertextuality, and at the semantic level - the use of methodological discourse. According to V. Fesenko, "the metadiscourse in the autobiographical text has the function of mirroring the very moment of writing as a speech situation” ${ }^{29}$.

\footnotetext{
${ }^{26}$ Аверинцев С. С. Судьба европейской культурной традиции в эпоху перехода от античности к средневековью / С. С. Аверинцев // Из истории культуры средних веков и Возрождения: Сб. статей / [Коллект. автор, Карпушин В. А.]. М. : Наука, 1976. С. 31.

27 Исаев С. Нежный / С. Исаев // Строгий надзор / Жан Жене; [Сост. С. Исаев]. М.: Изд-во «ГИТИС», 2000. С. 8.

${ }^{28}$ Genet J. Querelle de Brest / Jean Genet. Paris, Gallimard, 1953. P. 105.

${ }^{29}$ Фесенко В. I. Автобіографія: до проблеми жанрової ідентичності / В. І. Фесенко // Сучасні літературознавчі студії. Модуси автобіографічного письма. Збірник наукових праць / [Гол. ред. В. І. Фесенко]. Вип. 7. К.: Вид. центр КНЛУ, 2010. - С. 14.
} 
In J. Genet`s novel, there are explicitly and implicitly expressed references to his previous works, this methodological discourse manifests as a simple reflection in the author`s mind games: doubts about the accuracy of memories ("Le plus attristant, c'est que, $j$ 'y songe quelquefois, les plus nombreuses de ces créations sont absolument oubliées, bien qu'elles forment tout mon concert spirituel passé. Je ne sais même plus qu'elles furent $<\ldots>{ }^{\prime 30}$ ) and diligence in describing events (criticizing the bias of portrayed events, constantly questioning what word can characterize this or that fact in the best way, etc.). During the story, the narrator splits and the attention shifts from the speech act to a communicative act. Reflections on the appropriateness of the chosen narrative form (cannot be determined by what exactly it says: a poem, a drama, or just a book), the validity of the certain lexical items use, escaping in advance is a complicated reflection, "a kind of fictionalization in action" (V. Fesenko ${ }^{31}$ ), thanks to which the autobiographical text appears as a novel. The use of a method of discourse provides the reader with the text as the author wants.

Person`s actions shape his character in the best way, assessing which the opinions of others can significantly diverge. That is why there are significant differences between how a writer constructs his own image and what others see, it is noted in the article "Mirror Labyrinths of St. Genet" by Y. Pokalchuk. S. Rubinstein explained such a peculiarity of character construction as “one's own version of a person is far from being the most reliable" ${ }^{32}$. In addition, a human being is a social being and always has a certain number of masks (according to K. G. Jung), using the appropriate personality in a particular situation. Thus, the image created by the author of autobiographical literature is another mask, considering that J. Genet is trying on several masks at once, manifesting itself in many characters. When creating an artistic image, the documentary writer either offers the reader a peculiarly ornate image that has nothing to do with reality, or, on the contrary, seeks to identify himself with his own image, whenever possible by supplanting anything that contradicts him. There is also a third variant that J. Genet chose for himself. He realizes that something in his mental and physical life does not correspond to the created perfect image. Then the prose writer, as an artist, selects and collates the elements

\footnotetext{
${ }^{30}$ Genet J. Notre-Dame des Fleurs / Jean Genet. Lyon: Barbezat-L'Arbalète, 1948. P. 110.

${ }^{31}$ Фесенко В. I. Автобіографія: до проблеми жанрової ідентичності / В. І. Фесенко // Сучасні літературознавчі студії. Модуси автобіографічного письма. Збірник наукових праць / [Гол. ред. В. І. Фесенко]. Вип. 7. К.: Вид. центр КНЛУ, 2010. С. 8-18.

32 Рубинштейн С. Л. Избранные философско-психологические труды; Основы онтологии, логики и психологии / С. Л. Рубинштейн; РАН; Институт психологии \{Москва\}. М.: Наука, 1997. С. 134.
} 
he needs from life and rejects unnecessary contradictory designs. Such an image, according to L. Ginsburg, contains neither deception nor self-deception. Metadiscourse as a reference is intended to present to the reader self-perception of the author, his aesthetics.

The appearance of the narrator as a writer commenting on the process of writing occurs in the novels of J. Genet everywhere, not only at the beginning, at the end and at the crucial moments of the story. This characterizes the function of metadiscourse as a means of fictionalization; this prevents the text from being autobiographical, completely identifying the author and the protagonist.

Thus, we can claim that most of the features inherent in the autofictional narrative type exist in the works of J. Genet.

\section{The genre identification of Jean Jenet`s novels}

V. Colonna ${ }^{33}$ distinguished four types of autofiction:

- biographical (most similar to an autobiographical novel, where there is a changing and plotting of one's own past in order to give it a novel dynamic (“Confession” by J.-J. Rousseau));

- fantastic (there is a fantastic element, that is, the first-person author narrates about the facts and circumstances that trancend not only the true but also the possible (Dante`s Alighieri Divine Comedy);

- Mirroring (the author's presence is only reflected by all levels of the narrative. The best essence of mirroring autofiction is J. Genet 's term from the theory of narrative - "metalepsis"). (For example, M. Proust's novel "In Search of Lost Time”, by V. Colonna);

- intrusion (the author does not participate in the novel's intrigue, but acts only as a narrator, whose functions include comments on what is happening, reader's address, conversation, etc.).

Identification of Jean Genet's novels according to one of these categories is almost impossible, since only in "The Thief's Journal" the autofiction of biographical material is strongly marked. All other novels are a complex combination of several kinds of autofiction.

The novel by Jean Genet, "Miracle of the Rose", based on the reallife events of being in Mettray Penal Colony and Fontevrault prison, as the author-narrator-hero tells us of the first person, we refer it to nominal biographically-fantastic autofiction. The narrator repeatedly emphasizes on plotting of some events from the past throughout the story. The only

${ }^{33}$ Colonna V. L'Autofiction (Essai sur la fictionnalisation de soi en littérature), thèse de doctorat de l'E.H.E.S.S., sous la direction de G. Genette / V. Colonna. Paris: Ecole des Hautes Etudes en Sciences Sociales, 1989. 368 p. 
real person in "Miracle of the Rose" is Harcamone, as narrator himself reports. At the same time, the writer points out that the prototypes of all the heroes of the work are real people whom he met along the way. Along with these collective images, the prototype of which often is J. Genet himself, who puts their thoughts in their mouths, and in their actions unrealized fantasies and desires, we also find references to real people who organically entered the story because they were not part of the world in which the writer lived for a long time. That is, without the permission of real prototypes of his characters, J. Genet breaks into their lives, tells about the events the average person very carefully conceals, although it is forbidden by law. However, breaking the law in any field of activity is commonplace for a writer. The prose writer becomes a kind of biographer of individual petty thieves and great criminals, trying to heroize and glorify them. Genet interprets the biographies of the heroes in his own manner, makes sense of their murders, betrayals, thefts. Such a position by J. Genet gives us reason to agree with the autobiography of the biography because of the subjectivity of the biographer's perception, which is deduced in the work of S. Grog Bell and M. Yale "Revealing lives: autobiography, biography and gender" (Revealing lives: autobiography, biography and gender, 1990).

The author-narrator motivation to add or omit something while constructing images of his characters is the desire to write a lyric song, a poem to Harcamone, not the text: "Sans doute, je sais encore faire le noir en moi, et sur l'indication d'un souvenir, m'enivrer de mes histoires passées, les refaire ou les compléter selon le mode tragique qui transforme chacune d'elles en poème dont je suis le héros $<\ldots>$ ". 34 .

The fantastic element is clearly revealed only at the end of the work, when Harcamone becomes God and his heart turns into a rose. The narrator tries to give unreality to the only real image (Harcamone) throughout the work, sacralizing the figure of the killer, noticing the radiance around him as he walks, however, the fantastic character of the story is acquired only on the last pages of the novel, in the episode of the execution of Harcamone. The character is depicted in tones of fantastic hyperbole (he in his grandeur turns into a giant who does not fit into the camera, and the escorts become scanty as insects. They rush through his body and cannot find the heart to tear him out; the labyrinths of Harcamone 's soul are like mirrors, the escorts finally reach the secret room. Opening the door, the

${ }^{34}$ Genet J. Miracle de la rose // Oeuvres completes de Jean Genet / Jean Genet. II. Paris, Gallimard, 1952. P. 156. 
prison guards find themselves in front of a huge red rose of unprecedented beauty. This is the heart of Harcamone, looking into which, they die).

The third prose work by Jean Genet "Funeral Rites" is attributed to biographical-mirror autofiction. "The Most Outspoken Novel of the Genius Marginale” (by G. Singer) is dedicated to Jean Decarnen, a close friend of Jean Genet. He was a young Communist who died on August 19, 1944, in the battle for the liberation of Paris (the real basis of the novel's events related to war). However, the accidental death of a friend brings to the scene a whole gallery of fictional and bizarre characters, which are some kind of objection to the denial, the reflection of reflection. The work is undoubtedly autofictional, but the plan of historical time is so foregrounded that it sometimes pushes the personal to the "periphery" of the narrative. The main issues of the writer 's entire creativity in the "Funeral Rites" are analyzed not in the context of Jean Genet's "dubious" biography, but in the context of the day, and indirectly expresses the writer' $\mathrm{s}$ civic position. This brings the novel closer to “auto-socio-biographie” (A. Ernaux’s term).

In our opinion, J. Genet's novel "Querelle of Brest” (1947) was unjustifiably ignored by foreign researchers, since it did not fit into the defined framework of autofiction. However, based on the research of V. Colonnas, who in the term of autofiction favored fiction over autobiography (author`s story line), we will try to prove the autofictional nature of this novel.

In "Querelle of Brest", a protagonist named Querelle is highlighted and the narrator is the witness of the depicted events. However, the name of the novel, which, according to N. Nikolina's ${ }^{35}$ classification, belongs to the names of autobiographical works that have in their semantics a component of "space", contains an indication of the significance terrain for the writer. While traveling to his native France and the world, J. Genet visited Brest, a port town, a haven for criminals, prostitutes and thieves. In addition, telling the fictional history of Querelle, the narrator constantly mentions places where he was alone - Beirut, Morocco and others.

The absence of a coincidence of the author's name with that of the protagonist, however, does not call into question their similarity. They are both representatives of the marginalized world, homosexuals and thieves, the age of Querelle (27 years) the same as the age of J. Genet during his travels in France and visits to Brest. Querelle, is a sailor, and the writer

\footnotetext{
${ }^{35}$ Николина Н. А. Поэтика русской автобиографической прозы: Учебное пособие для студентов, аспирантов, преподавателей-филологов / Николина Наталья Анатольевна. М.: Флинта; Наука, 2002. 423 с. (Филологический анализ текста; Библиогр.: с. 400-421 (473 назв.) и в подстроч.примеч.).
} 
has dreamed of becoming a youngster in the Navy since his childhood, testimonies of which are found in numerous interviews and mentions, in other autobiographical works. The officer Seblon looks like an adult J. Genet, gentle and indecisive in his desire for the love of young boys.

$\mathrm{V}$. Colonna considers the primordial desire for freedom to be the main stimulus for autofiction. Restrained in real life by ethical and moral prejudices, social and religious restrictions, the author makes himself a hero of his own works, in order to experience and feel all that he would not dare to do in everyday life. J. Genet's desire for inclusive freedom, manifested in the vital and creative marginality, is poured into the pages of the novel to construct the perfect image of a completely free man, Querelle, who embodies all the unfulfilled desires of the writer and expresses his ethico-aesthetic concept. Commenting on the events of the novel, the narrator states: "Nous aimerions que ces réflexions, ces observations que ne peuvent accomplir ni formuler les personnages du livre, permissent de vous poser non en observateurs mais en créatures ces personnages qui, peu à peu, se dégageront de vos propres mouvement" ${ }^{\text {„3 }}$ or "Nous parlons encore de ce personnage idéal et héroïque, fruit de nos secrètes amours" 37 .

Among all autofictional novels of J. Genet "Querelle of Brest" is the only one where the story is told by the first person of the plural. This is one of the ways of identifying an author in any autobiographical work. And it is not so much about using the pronoun "we" in outlining the actions shared by the narrator and the person close to him or when pointing to a wide range of people connected to him by the common past. Recreating the story of sailor Querelle's life and his surroundings for a certain period, the narrator tries to justify homosexuality, murder, betrayal, but in other people's examples. He himself is like a commentator. That is why he uses the opposition "we - they", separating his world of thieves and prostitutes from "alien": "Pourtant, de sa jeunesse, nous rappellerons quelques faits. Nous pour dire que ces faits commanderons toute la psychologie de notre héros, mais afin de rendre plausible une attitude qui ne ressortit pas seulement à un simple choix" ${ }^{\text {"38. }}$.

However, the use of the plural first person pronoun at the same time brings the narrator closer to the reader, intensifies their relationship, which allows J. Jenet to hope for greater trust. It is in this way that he can talk openly about his teenage homosexuality, his desire for betrayal,

\footnotetext{
${ }^{36}$ Genet J. Querelle de Brest / Jean Genet. Paris, Gallimard, 1953. P. 24.

${ }^{37}$ Ibid. P. 21

${ }^{38}$ Ibid. P. 34-35.
} 
the murder from the mouth of Querelle, Roger, Gilles, “<...> qu'ils deviennent les héros même du contempteur"39: "Notre dessein n'est pas de dégager deux ou plusieurs personnages $-<\ldots>$ systématiquement odieux. Mais qu'on veuille plutôt considérer que nous poursuivons une aventure qui se déroule en nous-mêmes, dans la région la plus profonde, la plus asociale de notre âme <... ${ }^{\text {40 }}$. In the excerpts from Lieutenant Seblon's diary, which are constantly narrated by the narrator, the thoughts of adulthood J. Genet, who is fond of young boys, but he no longer seeks protection or maternal tenderness, he is ready to give them himself.

The addressing of "you" is a realization of the methodological discourse in the novel. Although the novel declares the presence of a fictitious reader, through such addressing the latter must identify himself with the implicit reader in order to understand the author's intentions. According to the type of discourse (by J. Genet), "Querelle of Brest" can be called authoritative, since the center of judgment for the reader in the fictitious world of the novel is the judgment, evaluation and remarks of the narrator. The main character of the simillary-name novel is an ordinary person who understands others' fears and flaws, and the narrator frankly says that he does not try to justify the killer, the betrayer and the theft, and aims to familiarize the reader with his philosophy, and also with his own. Achieving this goal is also facilitated by a wide range of functions of the autocratic discourse:

- communicative function (the author-narrator constantly communicates with the narrator. For example: "La scène que nous rapporterons est la transposition de l'événement qui nous révèla Querelle" $^{41}$ );

- metanarative function (narrator's commentary on his discourse: “<...> nous résolûmes d'écrire le roman (ce mot convient peu s'il sert à nommer une aventure ou suite d'aventures déjà vécues)" ${ }^{42}$ );

- descriptive and evaluative functions (use of epithets, comparisons that reflect the author's attitude to heroes and events): “< ..> nous désirons qu'il vous apparaisse que le matelot Querelle, né de cette solitude où l'officier lui-même restait reclus, était un personnage solitaire comparable à l'ange de l'Apocalypse dont les pieds reposent sur la mer" ${ }^{43}$.

\footnotetext{
${ }^{39}$ Genet J. Querelle de Brest / Jean Genet. Paris, Gallimard, 1953. P. 21.

${ }^{40}$ Ibid. P. 82.

${ }^{41}$ Ibid. P. 21.

42 Ibid. P. 21.

${ }^{43}$ Ibid. P. 11.
} 
So, come back to the classification of V. Colonna, we conclude that the novel "Querelle of Brest" is a specular autofiction-invasion, where the author-narrator, while telling about completely fictional events from the life of the fictional hero, at the same time very clearly reflects in it, makes him an expression of his own ethico-aesthetic concept, creates an image he would like to become himself but would never dare to contemplate, analyzes the results of his dreams, and is reflected in the text in the image of the writer.

\section{CONCLUSIONS}

Thus, despite the fact that the chronological boundaries of J. Genet's writing of his novels preceded the theoretical understanding of the genre of autofiction, researchers have determined that the fictionalization of autobiographical material has a much more ancient history and can be traced back to J.-J. Rousseau. However, from the unwilling autofiction of his predecessors, the writer move on to the conscious fictionalization. The author enters into a certain "game" with the reader, emphasizing the conventionality of his characters at the beginning and noting their closeness to himself after a certain time ("The above thoughts were heard and proclaimed by me. My feelings are also" ${ }^{44}$ ). In his pursuit of freedom, in all its manifestations, J. Genet goes on to make his own life more fabulised. Autofabulation as a novel rethinking of one's own intrapsychic disorders is a consciously chosen path for the artist to selfidentify. At the same time, J. Genet takes a leading role in the novels by fictionalizing as the embodiment of his dreams and fantasies. The part and role of fiction increases significantly from the autobiographical novels "Miracle of the Rose" and "The Thief`s Journal" to the most fictional "Querelle of Brest”.

Considering the presence in Jean Genet's prose of all the features of a hybridized autobiography - autofiction, we position the novels "Our Lady of the Flowers", "Miracle of the Roses", "Funeral Rites", "Querelle of Brest" and "The Thief's Journal" as autofiction works, in which factual (memoirs, diary, autobiography) and fictional (novel) traits are seamlessly combined. The autofictional mode of writing is a leading feature of contemporary autobiographical literature.

\footnotetext{
${ }^{44}$ Genet J. Pompes Funèbres / Jean Genet. Paris, Gallimard, 1953. P. 67.
} 


\section{REFERENCES}

1. Colonna V. L'Autofiction (Essai sur la fictionnalisation de soi en littérature), thèse de doctorat de l'E.H.E.S.S., sous la direction de G. Genette. Paris: Ecole des Hautes Etudes en Sciences Sociales, 1989. $368 \mathrm{p}$.

2. Darrieussecq M. L’autofiction, un genre pas sérieux // Poétique. № 107. septembre 1996. Pp. 369-380.

3. Doubrovsky S. Autobiographie / Vérité / Psychanalyse // Autobiographiques: de Corneille à Sartre. Paris: PUF, coll. "Perspectives critique”, 1988. P. 61-79.

4. Gasparini Ph. Est-il je? Roman autobiographique et autofiction. Paris: Editions du Seuil, Coll. Poétique. 2004. 393 p.

5. Gasparini Ph. Une aventure du langage. Paris: Le Seuil, 2008. 339 p.

6. Genet J. Journal du Voleur. Paris, Gallimard, 1949. 320 p.

7. Genet J. Miracle de la rose // Oeuvres completes de Jean Genet. II. Paris, Gallimard, 1952. 223 p.

8. Genet J. Notre-Dame des Fleurs. Lyon: Barbezat-L’Arbalète, 1948. 383 p.

9. Genet J. Pompes Funèbres. Paris, Gallimard, 1953. 307 p.

10. Genet J. Querelle de Brest. Paris, Gallimard, 1953. 247 p.

11. Laurent Th. L'oeuvre de Patrick Modiano: une autofiction. Lyon: Presses universitaires de Lyon, 1997. 188 p. (Includes bibliographical references, p. [185]-188).

12. Lecarme J. Autofiction: un mauvais genre // Autofictions et Cie. Actes du colloque des 20 et 21 novembre 1992 / [dir. S. Doubrovsky, P. Lejeune, J. Lecarm]. revue PITM. n 6. Paris. 1993. Pp. 227-249.

13. Lejeune P. Le pacte autobiographique. Paris: Ed. du Seuil, 1975. $330 \mathrm{p}$.

14. Vilain P. L' autofiction en théorie // Genèse et autofiction / [dir. J. L. Jeannelle et C. Viollet]. Louvain-la-Neuve: Bruylant-Academia, 2007. P. 70-75.

15. Аверинцев С. С. Судьба европейской культурной традиции в эпоху перехода от античности к средневековью // Из истории культуры средних веков и Возрождения: Сб.статей / [Коллект. автор, Карпушин В. А.]. М.: Наука, 1976. 316 с.

16. Гинзбург Л. Я. О психологической прозе / Гинзбург Лидия Яковлевна. Л. : Художественная литература, ЛО, 1977. 443 с. Библиогр. в подстроч. Примеч. 
17. Исаев С. Нежный // Строгий надзор / Жан Жене; [Сост. С. Исаев]. М.: Изд-во «ГИТИС», 2000, С. 7-22.

18. Николина Н. А. Поэтика русской автобиографической прозы: Учебное пособие для студентов, аспирантов, преподавателейфилологов. М.: Флинта; Наука, 2002423 с. (Филологический анализ текста; Библиогр.: с. 400421 (473 назв.) и в подстроч.примеч.).

19. Покальчук Ю. Дзеркальні лабіринти «святого» Жене // Покоївки: [П’єса] / Жан Жене ; [пер. із фр. та післямова Ю. Покальчука]. Львів: Кальварія, 2002. С. 80-125.

20. Рубинштейн С. Л. Избранные философско-психологические труды; Основы онтологии, логики и психологии. М.: Наука, 1997. 463 c.

21. Стахов Д. Святой? Комедиант? Мученик? // Новый мир. М., 1995. № 2. С. 236-239.

22. Фесенко В. І. Автобіографія: до проблеми жанрової ідентичності // Сучасні літературознавчі студії. Модуси автобіографічного письма. Збірник наукових праць / [Гол. ред. В. І. Фесенко]. Вип. 7. К.: Вид. центр КНЛУ, 2010. С. 8-18.

\section{Information about the author:} Semenets O. S., $\mathrm{PhD}$ in Philological Sciences, Head of the Foreign Philology Department, Academic and Scientific Institute of Philology and Journalism, V. I. Vernadskiy Taurida National University 33, John McCain str., Kyiv, 01042, Ukraine 